\title{
Notes on the vocalizations of Chestnut-breasted Wren (Cyphorhinus thoracicus)
}

Peter Boesman

In the following we briefly analyze and compare voice of the two races of Chestnut-breasted Wren (Cyphorhinus thoracicus). We also try to quantify the extent of any vocal differences using the criteria proposed by Tobias et al. (2010), as a support for taxonomic review. We have made use of sound recordings available on-line from Xeno Canto (XC).

A comparison of song of both races, illustrated with sonograms:

C. t. dichrous ( W \& C Andes of Colombia (S from Antioquia) S to N Peru (San Martín)) Colombia
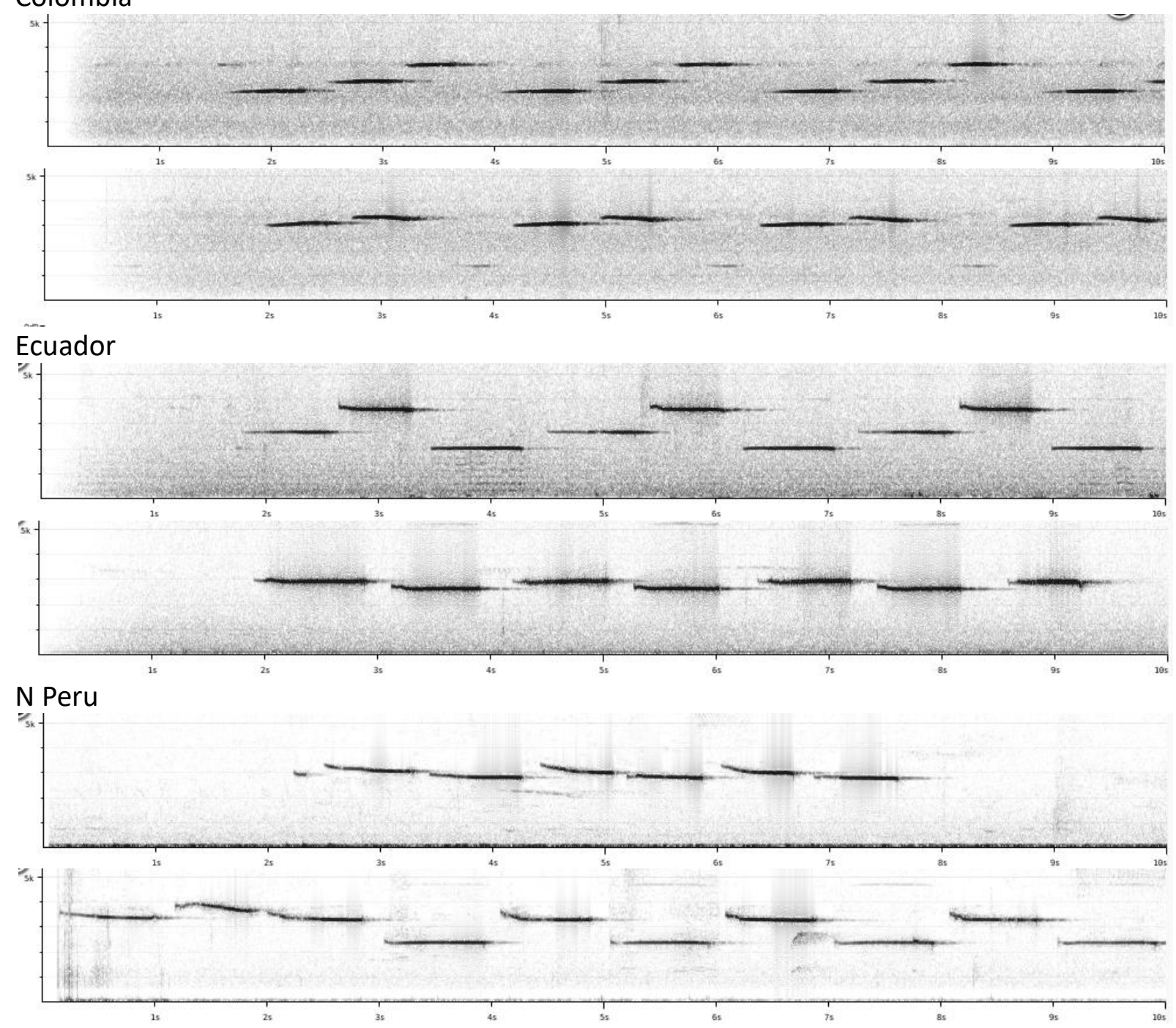


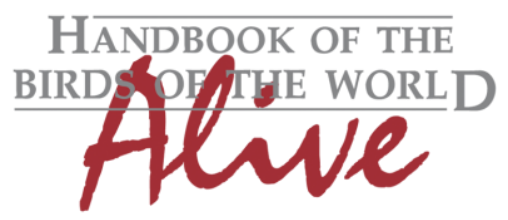

\section{ORNITHOLOGICAL NOTES}

C. t. thoracicus (Peru (Huánuco S to Puno) and W Bolivia)

Peru
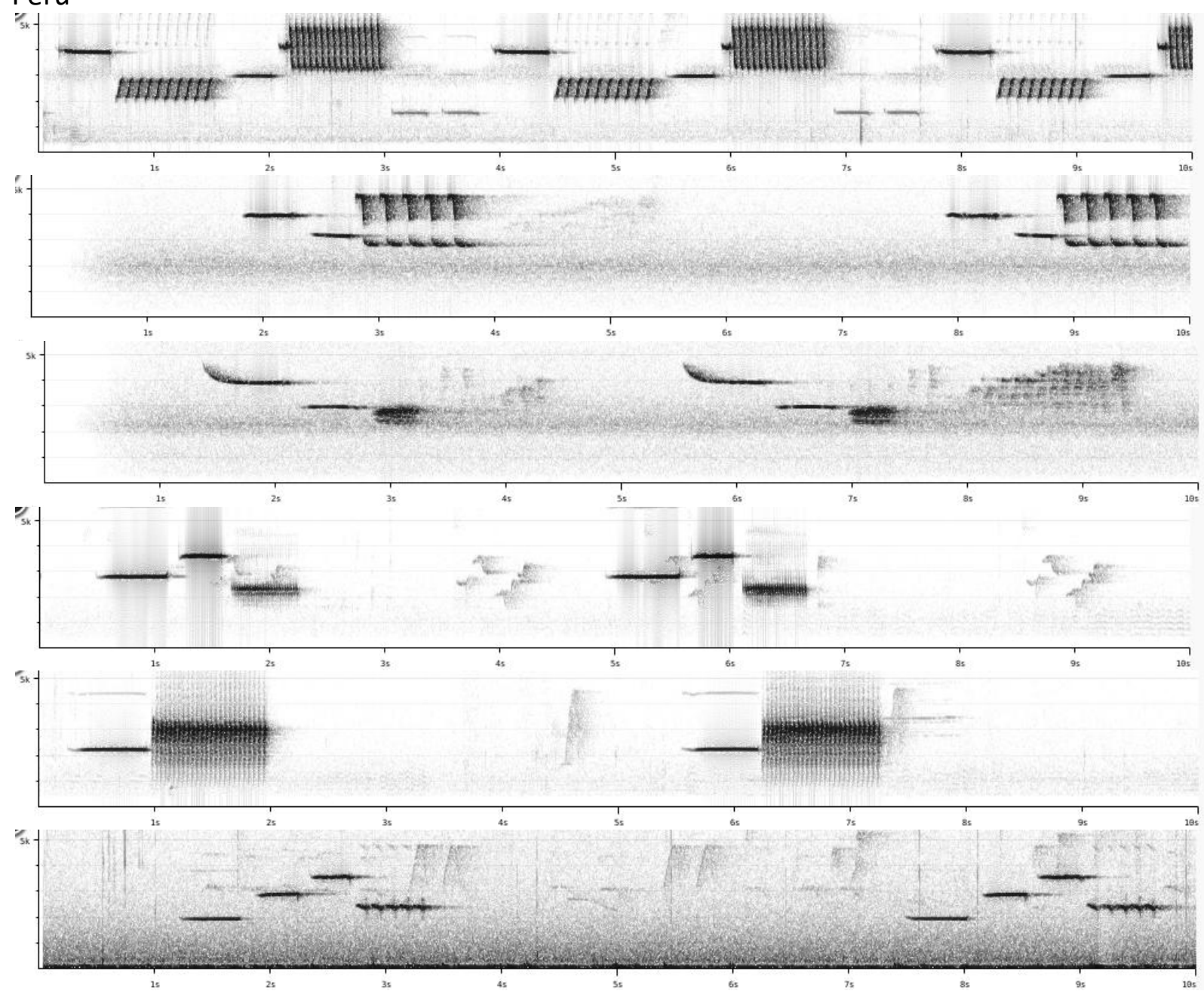

Bolivia

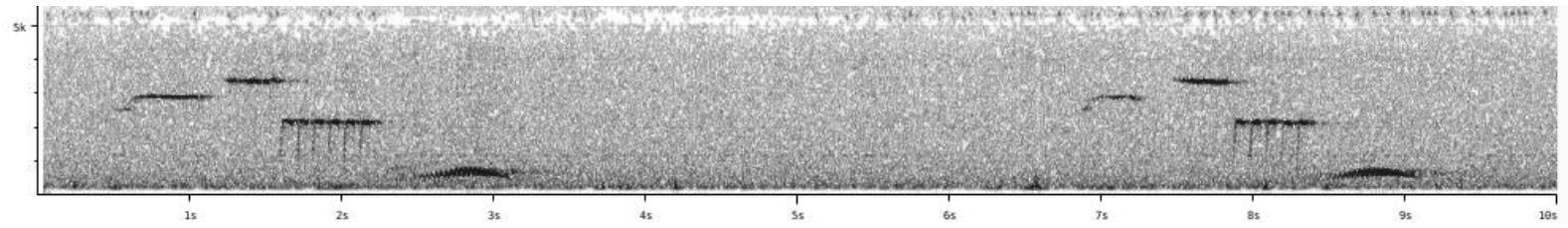

From the above examples it is quite clear that song of both races is different.

Schulenberg et al. (2007) already described this vocal difference: “...dramatic variation in VOICE. Song north of Maranon (dichrous) a haunting series of 2 or 3 melancholy whistled phrases repeated several times. Song south of Maranon (thoracicus) quite different, with varied song phrases that include trills, squeaks, purrs, and musical whistles".

Song of thoracicus is much more variable than song of dichrous, but despite this variability always seems to have a fast repeated series or trill, in some cases extremely fast. Song difference of thoracicus (vs. dichrous) can thus be quantified by the much higher number of notes in a song phrase (score 3-4), shorter minimum note length (score 3 ) and larger max. frequency range in single notes (score 2 ), due to these trills. 
Other differences are the more varied note shapes per song phrase in thoracicus (score 1-2) and the overall larger repertoire.

When applying Tobias criteria, this would lead to a total vocal score of about 6 .

This note was finalized on 20th June 2016, using sound recordings available on-line at that moment. We would like to thank in particular the many sound recordists who placed their recordings for this species on XC.

\section{References}

Schulenberg, T.S., Stotz, D.F., Lane, D.F., O’Neill, J.P. \& Parker, T.A. (2007). Birds of Peru. Princeton University Press, Princeton, New Jersey.

Tobias, J.A., Seddon, N., Spottiswoode, C.N., Pilgrim, J.D., Fishpool, L.D.C. \& Collar, N.J. (2010). Quantitative criteria for species delimitation. Ibis 152(4): 724-746.

\section{Recommended citation}

Boesman, P. (2016). Notes on the vocalizations of Chestnut-breasted Wren (Cyphorhinus thoracicus). HBW Alive Ornithological Note 295. In: Handbook of the Birds of the World Alive. Lynx Edicions, Barcelona. (retrieved from http://www.hbw.com/node/1251743 on 13 October 2016). 